\title{
Optimization of the osmotic dehydration of ginger
}

\section{Leonardo Pereira de Siqueira ${ }^{1}$ Leonie Asfora Sarubbo ${ }^{2}$ Neide Kazue Sakugawa Shinohara ${ }^{1}$ Marcela Sarmento Valencia ${ }^{3}$ Neila Mello Santos Cortez ${ }^{3}$ iD Samara Alvachian Cardoso Andrade An $^{3}$}

${ }^{1}$ Universidade Federal Rural de Pernambuco (UFRPE), Recife, PE, Brasil.

${ }^{2}$ Universidade Católica de Pernambuco (UNICAP), Recife, PE, Brasil.

${ }^{3}$ Universidade Federal de Pernambuco (UFPE), Recife, PE, Brasil. E-mail: neilacortez@yahoo.com.br. "Corresponding author.

ABSTRACT: The present research aimed to optimize the process of osmotic dehydration (OD) of ginger with hypertonic sucrose solution employing response surface methodology. A $2^{3}$ experimental planning was carried out and 17 experimental assays were performed based on three independent variables (temperature, concentration of the osmotic solution and immersion time) and three dependent variables (moisture loss (ML), solids gain (SG) and dehydration efficiency index (DEI)). The selected assay conditions exhibited the preferred DEI value (the highest $M L$ and lower $S G$ ), which were considered in the optimization. Assay 16 demonstrated to be the most favorable conditions for the osmotic dehydration of ginger $(\mathrm{DEI}=1.61)$ at $40 \quad 40^{\circ} \mathrm{C}, 50^{\circ} \mathrm{Brix}$ and 90 minutes of immersion time. Assay 1 performed at $34{ }^{\circ} \mathrm{C}$, $44{ }^{\circ} \mathrm{Brix}$ and 120 minutes of immersion time also displayed desirable response $(D E I=1.45)$. Thus, these two assays were evaluated for the presence of thermal-tolerant coliforms: Bacillus cereus and Salmonella sp.. The analyses presented values below the acceptable limits, which assured high quality hygienic and sanitary conditions of the product.

Key words: Zingiber officinale Roscoe, water loss, microbiological analysis.

Otimização da desidratação osmótica do gengibre

RESUMO: A presente pesquisa teve como objetivo otimizar o processo de desidratação osmótica (DO) do gengibre, com solução hipertônica de sacarose, pelo método de superficie de resposta. Foi utilizado um planejamento fatorial 23 completo, totalizando 17 ensaios, tendo como variáveis independentes: temperatura, concentração da solução osmótica e tempo de imersão e variáveis dependentes, como,: perda de umidade (PU), ganho de sólidos (GS) e índice de eficiência de desidratação osmótica (IED). Para otimizar foi considerado o melhor ensaio, o que obteve maior IED, ou seja, maior PU e menor GS. As melhores condições para a desidratação osmótica de gengibre foram obtidos a $40^{\circ} \mathrm{C}$, $50^{\circ}$ Brix e 90 minutos de imersão (Ensaio 16) com IED de 1.61 vindo em seguida o Ensaio 1 ( $34^{\circ} \mathrm{C}$, $44^{\circ}$ Brix e 120 minutos de imersão) com IED de 1.45. Estes ensaios foram avaliados quanto à coliformes tolerantes térmicas, Bacillus cereus e Salmonella spp., apresentando valores abaixo dos limites aceitáveis, indicando boas condições higiênicas sanitárias do produto.

Palavras-chave: Zingiber officinale, perda de água, análise microbiológica.

\section{INTRODUCTION}

Ginger (Zingiber officinalle) is native to Tropical Asia and the Malay Archipelago, but has been cultivated as a monoculture worldwide. In Brazil, the main crops are from Paraná and Santa Catarina, which together export approximately $70 \%$ of the national production to the Netherlands, Canada, Germany, and the United States (KIZHAKKAYIL \& SASIKUMAR, 2011).

Quality of ginger rhizomes is commonly affected after harvesting as a result of weight loss, wilting, surface wrinkling, physiological deterioration, attack of pathogens and physicochemical alterations in compounds such as a decrease in protein and crude fiber levels. These events can lead to lower product value and shelf-life (GARCÍA-TOLEDO et al., 2016).

The OD is a mass-transfer operation where water is partially removed through the immersion of products in hypertonic aqueous solutions such as syrups or brines and it may be a feasible alternative to increase shelf-life of products of plant origin (SIMPSON et al., 2015). Immersion of a product in a hypertonic solution creates a chemical gradient between the external and internal environment as the result of different osmotic potentials. During 
a dynamic period in the mass transfer process, water is transported from the food to the solution and, simultaneously, the solute is deposited on the product's surface (SOURAKI et al., 2014).

This operation has been widely studied in food processing and it has been used as an alternative for the pre-treatment of jenipapo (ANDRADE et al., 2007), radish (HERMAN-LARA et al., 2013) and cherry tomatoes (DEROSSI et al., 2015) because it can contribute to improving the quality of the final product (PEREIRA et al., 2006) regardless the reduction of some nutrients such as vitamins and minerals (CHAVARRO - CASTRILLÓ et al., 2006). In addition, OD is considered an energy-efficient method because water is removed from the product at mild temperatures (HERMAN-LARA et al., 2013).

Hence, this research aimed to optimize the process conditions of osmotic dehydration of ginger using response surface methodology with a hypertonic sucrose solution.

\section{MATERIALS AND METHODS}

Samples of fresh ginger rhizomes (Zingiber officinale) were randomly purchased in local markets (Recife, PE, Brazil) after being visually selected by color, size, and absence of physical damage. Granulated white sugar (União Coopersucar, Limeira, SP, Brazil) was used as the osmotic agent. After being properly sanitized, ginger roots were peeled, sliced $0.2 \mathrm{~cm}$ thick, and weighed. These samples were subsequently immersed in the osmotic sucrose solution and placed in a shaker (Marconi, MA-410) at $160 \mathrm{rpm}$ with controlled temperature and time. The assays were carried out in $600 \mathrm{~mL}$ sealed cylindrical glass containers. Approximately 20 $\mathrm{g}$ of ginger were dehydrated in $400 \mathrm{~g}$ of hypertonic solution (1:20 sample/solution ratio) to ensure the constant concentration in the osmotic solution.

An experimental study evaluated a $2^{3}$ factorial planning with eight factorial points $( \pm$ one level), three central points (level 0), and six axial points $( \pm \alpha)$, totaling 17 assays. The independent variables were: temperature $(\mathrm{T})$, osmotic solution concentration $(\mathrm{C})$, and immersion time $(\mathrm{t})$. The dependent variables were: moisture loss $(\mathrm{ML})$, solid gain $(\mathrm{SG})$, and the $\mathrm{ML} / \mathrm{SG}$ ratio = DEI. The obtained data were fitted to a polynomial function described by Equation 1 where $\beta_{\mathrm{n}}$ are the regression coefficients, $y$ is the response of interest (ML, SG, and ML/SG), and $T, C$, and $t$ are the independent variables.

$\mathrm{Y}=\varphi(T, t, C)=\beta_{0}+\beta_{1} T+\beta_{2} C+\beta_{3} t+\beta_{11} T^{2}+\beta_{22} C^{2}+$ $\beta_{33} t^{2}+\beta_{12} T C+\beta_{13} T t+\beta_{23} C t$
The evaluated conditions are presented in Levels $(-\alpha,-1,0,1$ and $+\alpha)$. The decoded levels of the independent variables are: Level $-\alpha\left(30^{\circ} \mathrm{C}, 40^{\circ}\right.$ Brix, and 90 minutes of immersion time); level $-1\left(34^{\circ} \mathrm{C}, 44\right.$ ${ }^{\circ}$ Brix, and 120 min of immersion time); level $0\left(40{ }^{\circ} \mathrm{C}\right.$, $50{ }^{\circ}$ Brix, and 165 min of immersion time); level 1 (46 ${ }^{\circ} \mathrm{C}, 56{ }^{\circ}$ Brix, and 210 min of immersion time), and level $+\alpha\left(50^{\circ} \mathrm{C}, 60^{\circ}\right.$ Brix, and $240 \mathrm{~min}$ of immersion time $)$.

The responses of interest were calculated as it is shown in Equations 2-4.

$$
\begin{aligned}
& M L(\%)=100 x \frac{(\text { UiMi }- \text { UfMf }}{M i} \\
& S G(\%)=100 x \frac{B f M f-B i M i}{M i} \\
& D E I=\frac{M L}{S G}
\end{aligned}
$$

Where: (3) $M i=$ initial mass $(\mathrm{g}) ; M f=$ final mass $(\mathrm{g}) ; \mathrm{ML}=$ moisture loss $(\%) ; U i=$ initial moisture content $(\%) ; U f=$ final moisture content $(\%)$; $\mathrm{SG}=$ solid gain $(\%) ; B i=$ initial soluble solids content in the material ( ${ }^{\circ}$ Brix); $B f=$ final content of soluble solids in the material ( ${ }^{\circ}$ Brix $)$; and DEI = dehydration efficiency index

The analytical determinations were performed in triplicate, before and after each osmotic treatment. Total soluble solids were determined by direct reading on a bench-top refractometer (AUS JENA). Moisture content (M) was determined at $105^{\circ} \mathrm{C}$ (AOAC, 2002; Method 985.14), and weight (W) was measured on an analytical balance. Statistical data analyses were performed in "Statistic for Windows 6.0" software (STATSOFT, 2002) at 5\% significance.

The presence of thermal-tolerant coliforms (NMP/mL) (AOAC, 2002; Method 991.14), Bacillus cereus CFU/g (AOAC, 2002), and Salmonella sp. (AOAC, 2002; Method 996.08) was evaluated in the microbiological analysis according to the provisions of Resolution - RDC $\mathrm{n}^{\circ} 12$ from January 2, 2001 (BRAZIL, 2001). The amounts of thermal-tolerant coliforms were determined in raw sample and the three samples which presented the highest DEI values in factorial planning assays in order to guarantee the microbiological safety of these products.

\section{RESULTS AND DISCUSSION}

The experimental results from 17 assays for ML, SG, and DEI are shown in table 1. During ginger $\mathrm{OD}$, the $\mathrm{ML}$ values were higher than the SG values in most of the assays. These results corroborate with the findings of SILVA et al. (2014) and BARBOSA JÚNIOR et al., (2013) reporting 
Table 1 - Results obtained for ML, SG, and DEI in the $2^{3}$ factorial planning of ginger osmotic dehydration.

\begin{tabular}{|c|c|c|c|c|c|c|}
\hline \multirow[t]{2}{*}{ Assay } & \multicolumn{3}{|c|}{ - } & \multicolumn{3}{|c|}{-------------Dependent variables------------ } \\
\hline & Temperature $\left({ }^{\circ} \mathrm{C}\right)$ & ${ }^{\circ}$ Brix & Immersion time (min.) & ML (\%) & SG $(\%)$ & DEI \\
\hline 1 & 34 & 44 & 120 & 42.13 & 28.96 & 1.45 \\
\hline 2 & 46 & 44 & 120 & 37.30 & 35.32 & 1.06 \\
\hline 3 & 34 & 56 & 120 & 50.18 & 38.56 & 1.30 \\
\hline 4 & 46 & 56 & 120 & 50.08 & 41.8 & 1.20 \\
\hline 5 & 34 & 44 & 210 & 38.33 & 33.25 & 1.15 \\
\hline 6 & 46 & 44 & 210 & 31.51 & 39.8 & 0.79 \\
\hline 7 & 34 & 56 & 210 & 50.86 & 38.4 & 1.32 \\
\hline 8 & 46 & 56 & 210 & 46.99 & 45.3 & 1.04 \\
\hline 9 & 40 & 50 & 165 & 45.67 & 37.56 & 1.21 \\
\hline 10 & 40 & 50 & 165 & 45.99 & 36.8 & 1.25 \\
\hline 11 & 40 & 50 & 165 & 44.62 & 37.9 & 1.18 \\
\hline 12 & 30 & 50 & 165 & 41.36 & 40.26 & 1.03 \\
\hline 13 & 50 & 50 & 165 & 42.47 & 47.89 & 0.89 \\
\hline 14 & 40 & 40 & 165 & 31.52 & 31.57 & 0.99 \\
\hline 15 & 40 & 60 & 165 & 55.99 & 39.9 & 1.40 \\
\hline 16 & 40 & 50 & 90 & 48.94 & 30.35 & 1.61 \\
\hline 17 & 40 & 50 & 240 & 44.09 & 36.9 & 1.19 \\
\hline
\end{tabular}

${ }^{*}{ }^{\circ}$ Brix: concentration of soluble solids; min: minutes; ML: Moisture loss; SG: Solid gain; DEI: Dehydration efficiency index.

the osmotic dehydration of pineapple and melon in sucrose solution, respectively. Lower SG values in osmotic dehydration are desirable since when SG values are higher than ML values, larger is the probability of modifications in the characteristics of the final product.

According to table 1, the highest $\mathrm{ML}$ $(55.99 \%)$ response was obtained in assay $15\left(40{ }^{\circ} \mathrm{C}\right.$, $60{ }^{\circ}$ Brix, and 165 min of immersion time), although the lowest SG value (28.96\%) was achieved in assay $1\left(34{ }^{\circ} \mathrm{C}, 44{ }^{\circ}\right.$ Brix, and $120 \mathrm{~min}$ of immersion time). The elevated moisture loss observed in the results of assay 15 may be related to the high concentration of the osmotic solution applied. An increase in the concentration of the osmotic solution implies an enhancement of osmotic pressure gradient and, consequently, higher mass transfer rates (SILVA et al., 2014). The SG value observed in assay 1 may be related to the conditions of low temperature, concentration, and immersion time. SG has a tendency to increase as the dehydration time and temperature increases. Therefore, shorter times and inferior temperatures lead to less structural changes in the product (MOURA, 2004).

The ideal level of solute absorption strongly depends on the purpose of the process and the desired characteristics in the final product. Thus, elevated DEI is indicative of a treatment that aims a large level of dehydration and low solid absorption (MATUSKA et al., 2006). Since this work aimed to maximize $\mathrm{ML}$ and minimize $\mathrm{SG}$, the selected responses for ginger OD with sucrose were those obtained in assay $16(\mathrm{DEI}=1.61)$ with $48.94 \% \mathrm{ML}$ and $30.35 \% \mathrm{SG}$, followed by assay 1 (DEI $=1.45)$ with ML $42.13 \%$ and $28.96 \%$ SG and assay 15 (DEI $=1.40$ ) with $55.99 \%$ ML and $39.90 \%$ SG. Therefore, assay 1 demonstrated the best osmotic conditions (34 ${ }^{\circ} \mathrm{C}, 44{ }^{\circ}$ Brix, and 120 min of immersion time) with the lowest SG values, which leads to a product that is the closest to that in natura.

Regression analysis was applied to model the values of dependent variables as quadratic functions of the osmotic solution concentration, temperature, and immersion time (Table 3). The effects of the independent variables on ML, SG, and DEI are presented in table 2. According to the data, the osmotic solution concentration displayed the greatest influence on ML, i.e., the increase in the osmotic agent concentration favored ML, which can be observed in figure 1 (a). This behavior may be attributed to the fact that the increase in the solution viscosity results in greater osmotic pressure, boosting the output of water from the food. However, based on the immersion time, this variable had little influence 
Table 2 - Effects of independent variables on ML, SG, and DEI.

\begin{tabular}{|c|c|c|c|c|c|c|}
\hline & ML & $\mathrm{p}$ & SG & $\mathrm{p}$ & DEI & $\mathrm{p}$ \\
\hline$\beta 0$ & 45.47 & 0.000 & 37.43 & 0.000 & 1.21 & 0.000 \\
\hline$\beta 1$ & -2.03 & 0.035 & 5.27 & 0.003 & -0.20 & 0.009 \\
\hline$\beta 11$ & -2.77 & 0.023 & 4.71 & 0.005 & -0.19 & 0.012 \\
\hline$\beta 2$ & 13.22 & 0.001 & 5.99 & 0.002 & 0.16 & 0.014 \\
\hline$\beta 22$ & NS & 0.078 & NS & 0.063 & NS & 0.460 \\
\hline$\beta 3$ & -2.96 & 0.017 & 3.40 & 0.008 & -0.21 & 0.008 \\
\hline$\beta 33$ & NS & 0.339 & -2.81 & 0.014 & 0.12 & 0.027 \\
\hline$\beta 12$ & NS & 0.063 & NS & 0.224 & NS & 0.065 \\
\hline$\beta 13$ & NS & 0.105 & NS & 0.137 & NS & 0.270 \\
\hline$\beta 23$ & NS & 0.071 & NS & 0.076 & 0.11 & 0.049 \\
\hline $\mathrm{R}^{2}$ & 0.965 & & 0.984 & & 0.908 & \\
\hline
\end{tabular}

*NS: not-significant ( $\mathrm{p}>0.05)$; ML: Moisture loss (\%); SG: Solid gain (\%), and DEI: Dehydration efficiency index. The regression coefficients represent: $\beta 0=$ average; $\beta 1=$ the linear term of temperature; $\beta 11=$ the quadratic term of temperature; $\beta 2=$ the linear term of osmotic solution concentration; $\beta 22=$ the quadratic term of osmotic solution concentration; $\beta 3=$ the linear term of immersion time; $\beta 33=$ the quadratic term of osmotic solution concentration; $\beta 12=$ term of the interaction between temperature and concentration of the osmotic solution; $\beta 13=$ term of the interaction between temperature and concentration of the osmotic solution; $\beta 23=$ term of the interaction between osmotic solution concentration and immersion time; $\mathrm{R}^{2}=$ determination coefficient.

on ML (Figure 1). These results corroborate those found by ABRAÃO et al. (2013) when studying the influence of osmotic dehydration parameters on the quality of pumpkins.

It can be observed that the osmotic solution concentration $\left({ }^{\circ}\right.$ Brix) and temperature were the variables with the greatest influence on SG (Table 2 ), i.e., the increase in osmotic agent concentration and temperature induced an increase in SG values, which are graphically represented in figure 1 . These findings are in accordance with those found by KHUMAR et al. (2012) on the osmotic dehydration of lychee, where the temperature was found to be the main variable to influence SG. According to the authors, increased processing temperature leads to decreased viscosity in the sugar solution, improving the mass transfer rates between the material and the hypertonic solution. Similar results were also reported by GENINA-SHAI et al. (2011) in a study on the effect of temperature and different concentrations of sucrose solutions during the osmotic dehydration of sweet potato cubes.

Elevated SG values in the process of osmotic dehydration are undesirable because they can lead to alterations in the product's sensory properties. Furthermore, when the impregnated solute concentration in plant tissues is high, the efficiency of dehydration is reduced due to the formation of an external barrier for the mass transfer mechanism (BORIN et al., 2008). However, there are processes when the incorporation of solutes on the surface of the product is desirable, such as the impregnation processes, in which the presence of solute provides desirable properties (BARBOSA JÚNIOR et al., 2013).

From the data in table 2 , it can also be highlighted that temperature and immersion time had a significant influence on DEI $(\mathrm{p}<0.05)$. Figure 1 (c) shows that the greatest DEI value was observed with the shortest immersion time and temperature of $40{ }^{\circ} \mathrm{C}$. The graph in Figure 1 (c) features downward concavity, which results from the negative quadratic term for temperature influence. According to ANDRADE et al. (2003) and TONON et al. (2006), when temperature increases above the threshold of plant tissue growth, it may cause damage that prevents water diffusivity and compromises the efficiency of the osmotic process.

The results from the analysis of variance (Table 3) show that the models adjusted to ML, SG, and DEI were predictive and presented significant regression and non-significant lack of fit. The coefficients of determination $\left(\mathrm{R}^{2}\right)$ were higher than 0.90 in all models, which means that the percentages of variation explained by the models were greater than $90 \%$. 


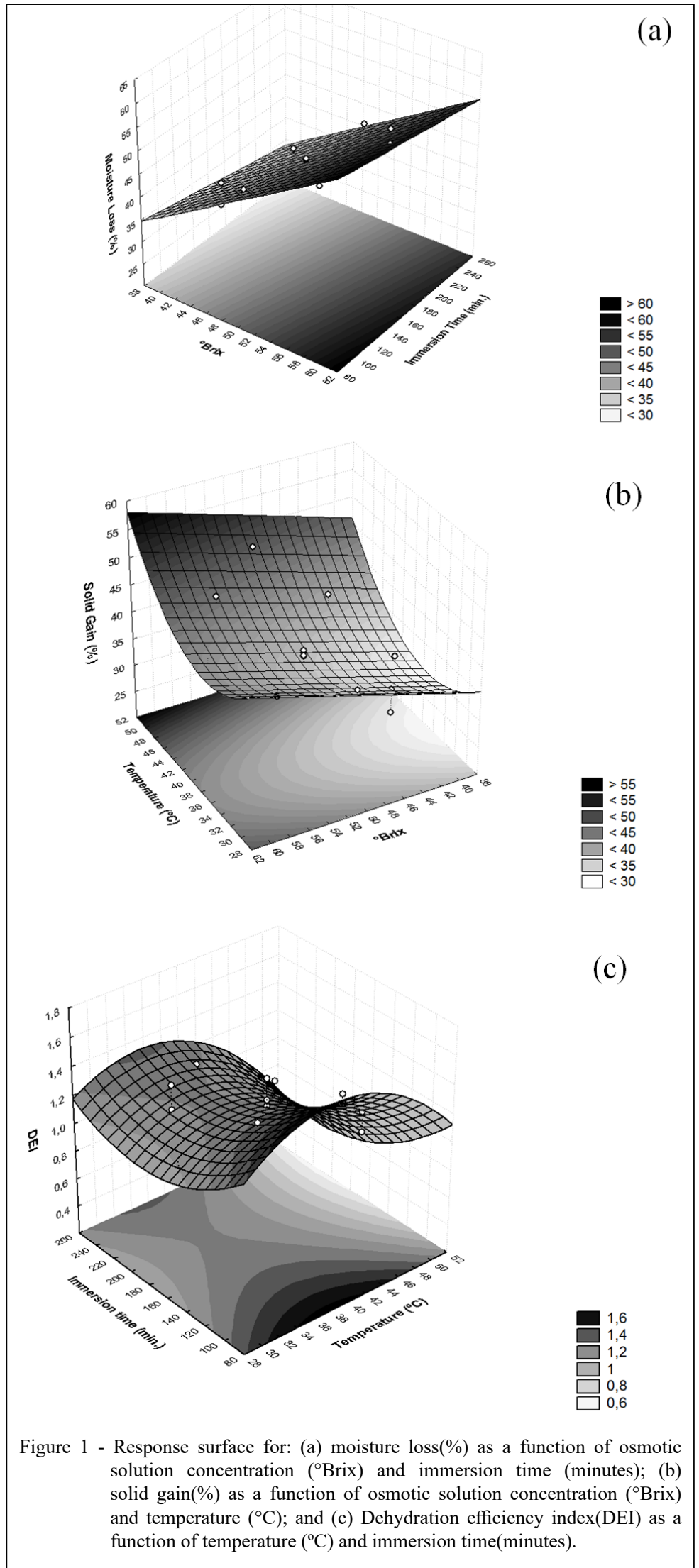

Ciência Rural, v.49, n.10, 2019. 
Table 3 - Variance analysis for the model adjusted to ML, SG, and DEI.

\begin{tabular}{|c|c|c|c|c|c|}
\hline Source of variation & DF & QS & QA & $\mathrm{F}_{\text {calculated }}$ & $\mathrm{F}_{\text {tabled }}$ \\
\hline Regression & 4 & 657.478 & 164.369 & 40.267 & 3.26 \\
\hline Residue & 12 & 48.981 & 4.082 & & \\
\hline Lack of fit & 10 & 47.954 & 4.795 & 9.347 & 19.4 \\
\hline Pure error & 2 & 1.027 & 0.513 & & \\
\hline Total & 16 & & & & $\mathrm{R}^{2}=0.965$ \\
\hline \multicolumn{6}{|l|}{ 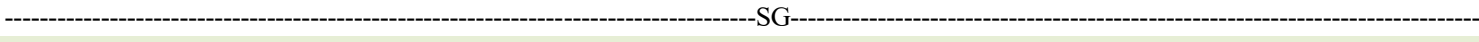 } \\
\hline Regression & 5 & 338.096 & 67.619 & 42.61 & 3.20 \\
\hline Residue & 11 & 17.463 & 1.587 & & \\
\hline Lack of adjustment & 9 & 16.829 & 1.870 & 5.90 & 19.4 \\
\hline Pure error & 2 & 0.634 & 0.317 & & \\
\hline Total & 16 & & & & $\mathrm{R}^{2}=0.984$ \\
\hline \multicolumn{6}{|l|}{ 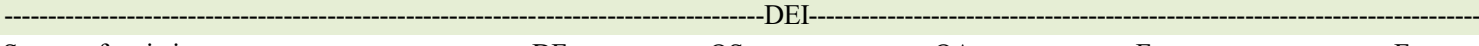 } \\
\hline Source of variation & DF & QS & QA & $\mathrm{F}_{\text {calculated }}$ & $\mathrm{F}_{\text {tabled }}$ \\
\hline Regression & 6 & 0.539 & 0.090 & 10.84 & 3.22 \\
\hline Residue & 10 & 0.083 & 0.0083 & & \\
\hline Lack of adjustment & 8 & 0.081 & 0.010 & 10 & 19.4 \\
\hline Pure error & 2 & 0.002 & 0.001 & & \\
\hline Total & 16 & & & & $\mathrm{R}^{2}=0.907$ \\
\hline
\end{tabular}

"ML: Moisture loss; SG: Solid gain; DEI: Dehydration efficiency index; DF: Degrees of freedom; QS: Quadratic sum; QA: Quadratic average; $\mathrm{R}^{2}=$ Determination coefficient

Ginger in natura and the two osmotically dehydrated ginger samples resulting from the assays 1 and 16 are in accordance with the standards established by Resolution RDC $\mathrm{N}^{\circ} 12$ (BRAZIL, 2001) for the presence of thermal-tolerant microorganisms (total coliforms NMP/mL, Bacillus cereus/g, and Salmonella $\mathrm{sp} . / 25 \mathrm{~g})$ indicating the appropriate sanitary and hygienic conditions of these products.

The advantages of osmotic dehydration are demonstrated in the acquisition of products with intermediate moisture, improved texture, and reduced losses of sensorial characteristics. Moreover, the reduction in energy costs in the subsequent stages of OD and the low-cost process are also valuable features in the OD process. Conversely, nutrient losses and solids gains are observed, which alter the in natura nutritional profile of the food.

The removal of moisture in the dehydration process favors the reduction of microbial activity and it provides a longer shelf-life product since microbiological and enzymatic activities are at acceptable levels. Furthermore, it is worth mentioning that the hygienic-sanitary procedures and best practices throughout product treatment are of great importance in the prevention of diseases and quality of the final product through the reduction of natural microbial loads present on plant surfaces.

\section{CONCLUSION}

The evaluation of parameters involved in the osmotic dehydration of ginger demonstrated that the concentration of the osmotic solution has a great influence on moisture loss and solids gains. Moreover, the dehydration efficiency index is greatly influenced by temperature and immersion time. The best conditions for the osmotic dehydration of ginger were obtained at $40{ }^{\circ} \mathrm{C}, 50^{\circ} \mathrm{Brix}$, and 90 minutes of immersion time with DEI of 1.61 and $34^{\circ} \mathrm{C}, 44^{\circ}$ Brix, and 120 minutes with DEI of 1.45. These assays were evaluated for the presence of thermal-tolerant coliforms, Bacillus cereus and Salmonella sp., and attested good hygienic and sanitary conditions in the dehydration of the product. Hence, the osmotic dehydration of ginger is a viable, applicable, cost-effective, and relatively simple technique that may be used by small industries or rural producers providing options with the potential of expanding this commercialization of the crop. 


\section{ACKNOWLEDGEMENTS}

And was financed in part by the Coordenação de Aperfeiçoamento de Pessoal de Nível Superior (CAPES), Brasil - Finance code 001.

\section{DECLARATION OF CONFLICT OF INTERESTS}

The authors declare that they have no conflict of interest. The founding sponsors had no role in the design of the study, nor in the data collection, analyses, or interpretation of data, the writing of the manuscript, nor the decision to publish the results.

\section{AUTHORS' CONTRIBUTIONS}

The authors contributed equally to the manuscript.

\section{REFERENCES}

ABRAÃO, A.S. et al.Influence of osmotic dehydration process parameters on the quality of candied pumpkins. Food and Bioproducts Processing, v.91, n.4, p.481-494, 2013. Available from: <https://doi.org/10.1016/j.fbp.2013.04.006>. Accessed: Jan. 15, 2016. doi: 10.1016/j.fbp.2013.04.006.

ANDRADE, S. A. C. et al. Osmotic dehydration of Jenipapo (Genipa americana L.). Ciência e Tecnologia de Alimentos, v.23, n.2, p.276-281, 2003. Available from: <http://dx.doi.org/10.1590/ S0101-20612003000200029>. Accessed: Jan. 15, 2016. doi: 10.1590/S0101-20612003000200029.

ANDRADE, S.A.C.et al.Influência de revestimentos comestíveis na redução de ganho de sólidos em jenipapos desidratados osmoticamente. Ciência e Tecnologia de Alimentos, v.27, n.1, p.39-43, 2007. Available from: <http://dx.doi.org/10.1590/S010120612007000100007>. Accessed: Mar. 25, 2016. ISSN 0101-2061.

AOAC. Association of Official Analytical Chemistry: Official Methods of Analysis (13. ed.). Washington:AOAC, 2002.

BARBOSA JÚNIOR et al. Mass transfer kinetics and mathematical modelling of the osmotic dehydration of orange-fleshed honeydew melon in corn syrup and sucrose solutions. International Journal of Food Science \& Technology, v.48, n.12, p.2463-2473, 2013. Available from: <http://onlinelibrary.wiley.com/doi/10.1111/ ijfs.12237/full>. Accessed: Mar. 03, 2016. doi: 10.1111/ijfs.12237.

BRASIL, Agência Nacional de Vigilância. Resolução - RDC n 12 , de 02 de janeiro de 2001. Regulamento técnico sobre padrões microbiológicos para alimentos. Diário Oficial da República Federativa do Brasil. 2001.

BORIN, I.et al. Efeito do pré-tratamento osmótico com sacarose e cloreto de sódio sobre a secagem convectiva de abóbora. Ciência Tecnologia de Alimentos, v.28, n.1, 3950, 2008. Available from: <http://dx.doi.org/10.1590/S010120612008000100008>. Accessed: Mar. 10, 2016. doi: 10.1590/ S0101-20612008000100008.

CHAVARRO - CASTRILLÓN et al. Efecto de la madurez, geometria y presión sobre la cinética de transferência de massaem La deshidratación osmóica de papaya (Carica papaya L., var. Maradol). Ciência e Tecnologia de Alimentos, Campinas, v.26, n.3, p596-603, 2006. Available from: $<$ http://dx.doi.org/10.1590/S010120612006000300018>. Accessed: Mar. 10, 2016. ISSN 1678-457X.

DEROSSI, A. et al. Study and optimization of osmotic dehydration of cherry tomatoes in complex solution by response surface methodology and desirability approach. Food Science and Technology, v.60, n.2, p.641-648, 2015. Available from: <http:// www.sciencedirect.com/science/article/pii/S0023643814006914>. Accessed: Mar. 12, 2016. doi: 10.1016/j.lwt.2014.10.056.

GARCÍA-TOLEDO, J.A. et al. Effect of osmotic dehydration on the physical and chemical properties of Mexican ginger (Zingiber officinale var. Gran Cayman). Journal of Food, v.14, n.1, p.27-34, 2016. Available from: <http://dx.doi.org/10.10 80/19476337.2015.1039068>. Accessed: Jun. 10, 2016. doi: $10.1080 / 19476337.2015 .1039068$

HERMAN-LARA, E. et al.Mass transfer modeling of equilibrium and dynamic periods during osmotic dehydration of radish in $\mathrm{NaCl}$ solutions. Food and Bioproducts Processing, v.91, n.3, p.216-224. 2013. Available from: <http://dx.doi.org/10.1016/j.fbp.2012.10.001>. Accessed: Jan. 05, 2016. doi: 10.1016/j.fbp.2012.10.001.

KIZHAKKAYIL, J.;SASIKUMAR, B. Diversity, characterization and utilization of ginger: a review. Plant Genetic Resources, v.9, n.3, p.464-477, 2011. Available from: <http://dx.doi.org/10.1017/ S1479262111000670>. Accessed: Jan. 10, 2016. doi: 10.1017/ S1479262111000670.

MATUSKA, M. et al.On the use of edible coatings to monitor osmotic dehydration kinetics for minimal solids uptake.Journal of Food Engineering, v.72, n.1, p.85-91. 2006. Available from: $<$ http://dx.doi.org/10.1016/j.jfoodeng.2004.11.023>. Accessed: Mar. 05, 2016. doi: 10.1016/j.jfoodeng.2004.11.023.

PEREIRA, L.M. et al.Kinetic aspects, texture, and color evaluation of some tropical fruits during osmotic dehydration. Drying Technology, v.24, n.4, p.475-484, 2006. Available from: <http:// dx.doi.org/10.1080/07373930600611968>. Accessed: May, 27, 2016. doi: 10.1080/07373930600611968.

SILVA, K.S. et al. Osmotic dehydration of pineapple with impregnation of sucrose, calcium, and ascorbic acid. Food and Bioprocess Technology, 7(2), 385-397, 2014. Available from: $<$ http://link.springer.com/article/10.1007/s11947-013-1049-0>. Accessed: May, 27, 2016. doi: 10.1007/s11947-013-1049-0.

SIMPSON, R. et al. Diffusion mechanisms during the osmotic dehydration of Granny Smith apples subjected to a moderate electric field. Journal of Food Engineering, v.166, p.204-211, 2015. Available from: <http://dx.doi.org/10.1016/j.jfoodeng.2015.05.027>. Accessed: May, 05, 2016. doi: 10.1016/j.jfoodeng.2015.05.027.

SOURAKI, B.A. et al. Correction of moisture and sucrose effective diffusivities for shrinkage during osmotic dehydration of apple in sucrose solution. Food and Bioproducts Processing, v.2, n.1, p.1-8, 2014. Available from: <http://dx.doi.org/10.1016/j.fbp.2013.07.002>. Accessed: May, 27, 2016. doi: 10.1016/j.fbp.2013.07.002.

Statsoft, Inc. STATISTICA for Windows 6.0 [Computer program manual], Tulsa- UK: StatSoft, 2002.

TONON, R.V. et al. Estudo da Desidratação osmótica de Tomate em Soluções Ternárias pela Metodologia de Superfície de Resposta. Ciência Tecnologia de Alimentos, v.3, n.26, p.715-723, 2006. Available from: <http://www.scielo.br/pdf/cta/v26n3/31780>. Accessed: Jun. 10, 2016. doi: 10.1590/S0101-20612006000300036.

Ciência Rural, v.49, n.10, 2019. 